Funding: None.

Competing interests: AWJ and PCG are affiliated with the Nordic Cochrane Centre. The views expressed in this article represent those of the authors and are not necessarily the views or the official policy of the Cochrane Collaboration.

1 Lexchin J, Bero LA, Djulbegovic B, Clark O. Pharmaceutical industry sponsorship and research outcome and quality: systematic review. $B M$ 2003;326:1167-70.

2 Bekelman JE, Li Y, Gross CP. Scope and impact of financial conflicts of interest in biomedical research: a systematic review. JAMA 2003;289:45465.

3 Als-Nielsen B, Chen W, Gluud C, Kjaergard LL. Association of funding and conclusions in randomized drug trials: a reflection of treatment effect or adverse events? JAMA 2003;290:921-8

4 The Cochrane Collaboration. The Cochrane Collaboration-principles. www.cochrane.org/docs/tenprinciples.htm (accessed 18 Sept 2006).

5 Jadad AR, Cook DJ, Jones A, Klassen TP, Tugwell P, Moher M, et al. Methodology and reports of systematic reviews and meta-analyses: a comparison of Cochrane reviews with articles published in paper-based journals. son of Cochrane reviews wi

6 Jadad AR, Moher M, Browman GP, Booker L, Sigouin C, Fuentes M, et al Systematic reviews and meta-analyses on treatment of asthma: critical evaluation. BMJ 2000;320:537-40.

7 Oxman AD, Guyatt GH. Guidelines for reading literature reviews. Can Med Assoc J 1988;138:697-703.

8 Jadad AR, McQuay HJ. Meta-analyses to evaluate analgesic interventions: a systematic qualitative review of their methodology. J Clin Epidemiol 1996;49:235-43.

9 Oxman AD, Guyatt GH. Validation of an index of the quality of review articles. J Clin Epidemiol 1991;44:1271-8.

10 Berlin JA. Does blinding of readers affect the results of meta-analyses? Lancet 1997;350:185-6.
11 Moja LP, Telaro E, D’Amico R, Moschetti I, Coe L, Liberati A. Assessment of methodological quality of primary studies by systematic reviews: of methodological quality of primary studies by systematic revi
results of the metaquality cross sectional study. BMJ 2005;330:1053.

12 Konstam MA, Weir MR, Reicin A, Shapiro D, Sperling RS, Barr E, et al. Cardiovascular thrombotic events in controlled, clinical trials of rofecoxib. Circulation 2001;104:2280-8

13 Jüni P, Nartey L, Reichenbach S, Sterchi R, Dieppe PA, Egger M. Risk of cardiovascular events and rofecoxib: cumulative meta-analysis. Lancet 2004;364:2021-9.

14 Cochrane Collaboration. Commercial sponsorship and the Cochrane Collaboration. www.cochrane.org/docs/commercialsponsorship.htm (accessed 16 June 2005).

15 Gøtzsche PC. Steroids and peptic ulcer: an end to the controversy? J Intern Med 1994;236:599-601.

16 Katerndahl DA, Lawler WR. Variability in meta-analytic results concerning the value of cholesterol reduction in coronary heart disease: a metameta-analysis. Am J Epidemiol 1999;149:429-41.

17 Chalmers TC, Berrier J, Sacks HS, Levin H, Reitman D, Nagalingam R. Meta-analysis of clinical trials as a scientific discipline. II: replicate variability and comparison of studies that agree and disagree. Stat Med 1987;6:733-44.

18 Linde K, Willich SN. How objective are systematic reviews? Differences between reviews on complementary medicine. J R Soc Med 2003;96:1722.

19 Gøtzsche PC, Pødenphant J, Olesen M, Halberg P. Meta-analysis of second-line antirheumatic drugs: sample size bias and uncertain benefit. J Clin Epidemiol 1992;45:587-94.

20 Cook DJ, Reeve BK, Guyatt GH, Heyland DK, Griffith LE, Buckingham L, et al. Stress ulcer prophylaxis in critically ill patients: resolving discordant meta-analyses. JAMA 1996;275:308-14

21 Olsen O, Gøtzsche PC. Screening for breast cancer with mammography. Cochrane Database Syst Rev 2001;(4):CD001877.

22 Hopayian K. The need for caution in interpreting high quality systematic reviews. BMJ 2001;323:681-4.

(Accepted 23 August 2006)

doi 10.1136/bmj.38973.444699.0B

DRUG POINTS

\title{
Epileptic seizures can follow high doses of oral vardenafil
}

Pasquale Striano, Federico Zara, Carlo Minetti, Salvatore Striano

\section{Case report}

An otherwise healthy 60 year old man was prescribed 10 $\mathrm{mg}$ of vardenafil (Levitra, Bayer) for sexual dysfunction. Because this was ineffective, he increased the dose to 40 $\mathrm{mg}$. Three hours later, he had a tonic-clonic seizure, seen by his relatives. On admission to hospital, neurological examination, brain magnetic resonance imaging, and electroencephalography after sleep deprivation were normal. Stress electrocardiography, echocardiography, and cardiac scan with dipyridamole test as well as carotid doppler ultrasonography did not show concomitant cardiac diseases. The man was told to stop using vardenafil.

Two months later he had a new tonic-clonic seizure, four hours after taking $30 \mathrm{mg}$ of vardenafil. At eight months' follow-up he is seizure-free without treatment.

\section{Discussion}

In this man, the seizures were unlikely to be the manifestation of other diseases: a complete screening ruled this out. And in both occasions seizure occurred within a few hours after he took vardenafil.

Vardenafil is a selective oral phosphodiesterase type 5 (PDE5) inhibitor effective in erectile dysfunction. ${ }^{1}$ Adverse events include headache, flushing, nasal congestion, and dyspepsia. ${ }^{12}$ Convulsions were not reported to Bayer during clinical trials of vardenafil. ${ }^{12}$ However, people taking sildenafil (Viagra, Pfizer), another inhibitor of this type, have had seizures. ${ }^{3}$

PDE5 inhibitors increase nitric oxide leading to increased cyclic guanosine monophosphate (cGMP), with relaxation of the smooth muscle in the corpus cavernosum and increased blood flow to the penis. ${ }^{12}$ Recent evidence indicates that these inhibitors may increase effects mediated by nitric oxide. Although the role of nitric oxide in the pathophysiology of epilepsy remains debated, the effects of nitric oxide and cGMP signalling pathway on seizure threshold ${ }^{4}$ raise the possibility that nitric oxide may mediate mechanisms that alter susceptibility to seizure. Furthermore, sildenafil has shown a pro-convulsant effect on seizure threshold, interacting with exogenously and endogenously released nitric oxide. ${ }^{5}$ However, the exact role of PDE5 in altering susceptibility to seizure via this pathway remains unclear.

After we submitted this drug point, a 78 year old patient presented with partial epileptic seizure after oral intake, for the second time, of $10 \mathrm{mg}$ of vardenafil. ${ }^{6}$ This confirms that epileptic seizures may occur during treatment with phosphodiesterase inhibitors.

Funding: None.

Competing interests: None declared.

1 Keating GM, Scott LJ. Vardenafil: a review of its use in erectile dysfunction. Drugs 2003;63:2673-703.

2 Hatzichristou D, Montorsi F, Buvat J, Laferriere N, Bandel T, Porst H. The efficacy and safety of flexible-dose vardenafil (Levitra) in a broad population of European men. Eur Urol 2004;45:634-41.

3 Gilad R, Lampl Y, Eshel Y, Sadeh M. Tonic-clonic seizures in patients taking sildenafil. BMJ 2002;325:869.

4 Przegalinski E, Baran L, Siwanowicz J. The role of nitric oxide in chemically- and electrically-induced seizures in mice. Neurosci Lett 1996;2173:145-8.

5 Riazi K, Roshanpour M, Rafiei-Tabatabaei N, Homayoun H, Ebrahimi F, Dehpour AR. The proconvulsant effect of sildenafil in mice: role of nitric oxide-cGMP pathway. Br J Pharmacol 2006;147:935-43.

6 Koussa S, Hage Chahine S, Tohme A, Riachi M. Epileptic seizures and vardenafil. Rev Neurol (Paris) 2006;162:651-2.

doi $10.1136 /$ sbmj. 38953.758565 .79
Department of

Neurological

Sciences, Federico

II University,

Napoli, Via Pansini,

80131, Napoli, Italy

Pasquale Striano

consultant

Salvatore Striano

professor of neurology

Muscular and

Neurodegenerative

Disease Unit,

Institute G Gaslini,

University of

Genova, Genova,

Italy

Federico Zara

researcher

Carlo Minetti

professor of

paediatrics

Correspondence to:

S Striano

sstriano@libero.it

BMJ 2006;333:785 